\title{
Ulus Ötesi İtibar Yönetimi: Türk İnternet Haberciliğinde Kanada Başbakanı
}

\author{
Dr. Öğr. Üyesi Aytuğ MERMER ÜZÜMLÜa, b
}

Özet

$\mathrm{Bu}$ çalışmanın amacı itibar yönetimi kavramını siyasal iletişimdeki yansımaları ile medya pratikleri arasındaki etkileşimi ortaya koymaktır. İlk bölümde siyasal iletişimde itibar yönetimine ilişkin genel bir çerçeve çizilirken devamında bu alandaki güncel eğilimlerden yeni siyaset kavramına değinilerek, kavramın itibar ve imaj üretme ile yönetme konularında medya uygulamalarında yarattığı dönüşüm değerlendirilmektedir. İkinci bölümde yeni siyaset anlayışının itibar yönetimine sunduğu açllımlar üzerine temellendirilen uygulama kısmı yer almaktadır. Bu bölümde yeni siyaset pratikleri Kanada Başbakanı Justin Trudeau'nun ülkesinden servis edilen haberlerinin uluslararası haber ajansları dolayımıyla Türk medyasındaki sunumu analiz edilmektedir. Analiz Kanada Başbakanı Justin Trudeau'nun Türk medyasında itibar yönetiminin sunumu ile kimlik konumlandırmasındaki yeni siyaset eğilimini ortaya koymak için bir yıllık süreçte konu olduğu tüm haberlerin içerik analizi ile incelenerek değerlendirilmesini kapsamaktadır. Analiz bulguları neticesinde mevcut Kanada hükümetinin dış politikada lider kimliği üzerinden itibar yönetimi sürecini yürüttüğü, bu sürecin yeni siyaset unsurlarını taşıdığı, Başbakan Trudeau'nun sempatik ve sorun çözücü bir imaj ile medyada konumlandırıldığı sonucuna varılmaktadır.
Anahtar Kelimeler

İtibar yönetimi

Halkla ilişkiler

Lider imaji

Justin Trudeau

Makale Hakkında

Geliş Tarihi: 01.10.2019

Kabul Tarihi: 13.03.2020

Doi: $10.18026 /$ cbayarsos.627978

\section{International Reputation Management: Canadian Prime Minister in Turkish Internet Journalism}

\begin{abstract}
The aim of this study is to reveal the reflections of transformations in the field of reputation management and media practices. In the first section, in which are the theoritical framework, the history of political communication, political marketing, election campaigns and their new aims in the politics are explicated. The second part of the study is the research part which is based on the opportunities offered by the new politics to political communication is included. In this section, the practices evolving from traditional politics to new politics are analyzed in the Turkish media through the presentation of the acts served by Justin Trudeau who is the Prime Minister of Canada, from his country through international news agencies. The analysis includes how the Prime Minister Justin Trudeau is presented in the Turkish media with an identity positioning and whether or not there are new politics tendencies in this position. As a result, it has been revealed that the Canadian government has made an identity positioning through the leadership identity in foreign policy and this situation carries new politics elements.
\end{abstract}

Keywords

Reputation management

Public relations

Leader image

Justin Trudeau

About Article

Received: 01.10.2019

Accepted: 13.03 .2020

Doi: $10.18026 /$ cbayarsos.627978

a İletişim Yazarı: aytug.mermer@amasya.edu.tr

b Dr. Öğr. Üyesi, Amasya Üniversitesi, https://orcid.org/0000-0001-6410-4974 


\section{Giriş}

Teknolojik değişimler, toplumsal hareketler, göç ve eğitim neticesinde yaşanan sosyal dönüşümler yirminci yüzyılın ikinci yarısından itibaren seçmen ve siyasi partiler arasında kurulan iletişimin daha simetrik olması yönünde açılımlar sunmuştur. Özellikle medyanın toplumsal hayattaki ağırlığının artmasının da etkisiyle siyaset geleneksel formundan sıyrılarak yeni bir biçim almaya başlamıştır. Siyasal icra sürecinin, vaat ettiği demokratik kazanımları siyasal iletişimin etkinliği ile tamamlayabileceği fikri Amerika'dan başlayarak tüm dünyaya yayılırken, siyasal iletişimi de medya ile yakın ilişki kurmaya yöneltmiştir.

Temsili demokrasilerde geleneksel siyaset, çoğu zaman seçmenin hakkında hiçbir özel fikir sahibi olmadığı siyasal aktöre oy verdiği dönemin ardından, siyasetçinin sınırlı sayıda seçmene ulaşarak özel niteliklerini ve yeni dönem vaatlerini aktardığ 1 sürece evrilmiş, kitle iletişim araçlarının gelişimi ile birlikte ise yüz yüze kurulan sınırlı ilişki geniş kitlelere yayılarak ulaşma fırsatı bulmuştur. Böylelikle yurttaşlar kendini temsil edecek siyasal figürün fikri yapısı, fiziksel görünüşü, gelecekteki projeleri hakkında daha detaylı bilgiye ulaşabilme imkânı yakalamıştır. "Kitle iletişim araçlarının toplumsal yaşamda ağırlığı giderek artarken, bu araçların bilgilendirme ve kamuoyu oluşturma fonksiyonuna paralel olarak medyanın siyasal yaşam üzerindeki etkisi siyaset ve iletişim bilimleri arasındaki yakınlığı da artmıştır" (Tokgöz, 1986). Bahsi geçen yakınlık politik figürün itibar yönetimi temellinde siyasetin yeni bir forma bürünmesine yol açmıştır.

İletişim teknolojilerindeki gelişmeyle paralel olarak önem kazanan kitle iletişimi, sosyolojik anlamda da bir dönüşüm yaratmış, geleneksel toplumsal bağlar zayıflarken, yeni toplumsal ve siyasal yapının form almasında etken konuma geçmiştir. Böylece, "kamuoyu oluşturmanın yolunun yazılı, sözlü ve görüntülü kitle iletişim araçlarından geçtiği düşüncesi yaygınlaşmış, ortaya çıktıkları zaman dilimine paralel olarak, 19. yüzyılın ikinci yarısından itibaren yazılı basın, 20. yüzyılın ilk yarısında radyo ve ikinci yarısından sonra da televizyon toplumda hızla yaygınlık kazanırken, beraberinde, medya önemli bir politik ve ekonomik silaha dönüşmüştür" (Meyer, 2004). Bahsi geçen silah, kitle iletişim araçlarından en verimli şekilde yararlanan siyasileri iktidara taşıyacak kudrette addedilmektedir. Zira televizyonun tek başına dahi "oy verme oranının düşmesi, yaşamsal sorunların siyasal kampanyalarda bilinçli olarak göz ardı ettirilmesi, siyasi partilerin giderek zayıflaması, liderlerin ve hükümetlerin sorun çözen taktikler yerine simgesel taktikler kullanmaya başlamaları ve siyasal sistemdeki diğer sorunlar da dahil olmak üzere siyasetin çehresini değiştiren bir çok olguya yol açtığı" söylenebilmektedir (Iyengar, 1997). Her ne kadar başlangıçta, "kitle iletişim araçlarının sadece siyasi kadroların mesajlarını halka ulaştırmakla kalmaması, aynı zamanda siyasi sistemi denetleme işlevi de görmesiyle siyasal bilgi edinme ve siyasal ilgi düzeyini artırmaya da katkıda bulunması" (Tokgöz, 1986) sevindirici bir dönüşüm olarak değerlendirilse de zaman içinde medyanın siyasal süreçteki etken duruşunun; yurttaşların siyasal ilgilerini, partilerin ortaya çıkışına yol açan ideolojik temellerin farkındalığını geri plana alarak, siyasetten uzaklaşmalarına yahut siyasetin sadece aktüel boyutuyla ilgilenmelerine yol açtı̆̆ı düşüncesiyle eleştirilere hedef olmuştur. Siyasal enformasyonun medya mantığına uygun dizayn edilmesi yurttaşların detaylı ve bağlamsal içerikten azade, özetlenmiş, kolay anlaşılır, heyecan verici, eğlenceli öğelere odaklanmasına neden olmuştur. Bu durum aktif seçmeni, pasif seyirciye dönüştürmüştür.

Medyanın politik bir silah olarak algılanmaya başladığı süreç, senkronize bir biçimde geleneksel siyasal kampanyaların ağırlığını kaybederek yeni siyaset formuna dönüştüğü zamana tekabül etmektedir. 1950'lerle beraber önce Amerika Birleşik Devletleri'nde başlayan 
yeni siyaset yaklaşımı, ilerleyen yıllarda dünyanın birçok bölgesine yayılmıştır. Partilerin iletişim biçiminin dönüşmesini tanımlayan kavram, "teknolojik yeniliklere bağlı olarak kitle iletişim araçlarının ve pazarlama tekniklerinin propaganda faaliyetlerinde yoğun biçimde kullanılmasını" ifade etmektedir (Negrine, 1996).

Bahsi geçen yeni siyaset yapma biçimi özünde lider odaklı bir itibar yönetimini temel almaktadır. Bu süreç, geleneksel parti örgütlerinin rolünün azalması, ağırlıklı olarak kitle iletişim araçları üzerinden yürütülen lider söylemlerini yansıtan iletilerin kamuoyuyla buluşturulması, medya vasıtasıyla inşa edilen lider imajı, geleneksel parti örgütlerinin yürüttüğü seçim kampanyalarının uzmanlar tarafından yürütülmesi, teknokrat olarak nitelenen uzmanların ve akademisyenlerin siyasal örgütlerde iletişime yön vermesi, yine geleneksel parti örgütleri tarafından sağlanan bilgilerin kamuoyu araştırmaları ile edinilmesi ve elektronik medya üzerinden kurulan iletişimin her geçen gün ağırlığının artması (Plasser vd, 2002) nüvelerini göstermektedir.

$\mathrm{Bu}$ çerçevede çalışmanın problemini Amerika Birleşik Devletlerinde başlayıp dünyaya yayılan yeni siyaset eğiliminin Türkiye medyasındaki yansımaları ile itibar yönetimi sürecinde belirginleşen etkileşimin irdelenmesi oluşturmaktadır. Bu doğrultuda, çalışma içerisinde ülke liderinin uluslararası medyada kişisel özelliklerini ön plana çıkarılıp çıkarılmadığı, iletişim dilinde liderin kendini ülkesinin taşıyıcı lokomotifi olarak işaret edip güven inşa etmeye çalışıp çalışmadığı, siyaset dışı alanlarda kişilik özelliklerinin konumlanıp konumlamadığı, halkla arasında lider-yurttaş ilişkisinden daha yakın (akrabalık, arkadaşlık, dostluk vb.) bir ilişki olduğunu vurgulayıp vurgulamadığı, özel hayatına dair detayları kamuoyuyla paylaşıp paylaşmadığı gibi yeni siyaset anlayışının öncelediği dolaylı soruların da cevapları aranmaktadır.

\section{Siyasal İletişimde İtibar Yönetimi}

Siyasal iletişimin başlangıç noktası esasen milattan öncesine Aristo'ya kadar dayanmaktadır. Aristo Retorik adlı eserinde Atina yurttaşlarının ortak iyiye ulaşabilmenin yolunun siyasal olan ile iletişimsel olanın birliğinden geçmekte olduğunu ifade etmektedir. Aristo'dan sonra çağlar boyu yöneticiler, yönetilenler ile yönetim biçimlerine göre farklılık gösterse de iletişim çabasında olmuştur. Ancak bugünkü haliyle "siyasal iletişimin sisteme dâhil olması ve hatta akademik bir alan sayılması 20. yüzyılın ikinci yarısından sonrasına tekabül etmektedir. Bu kavramın II. Dünya Savaşı sonrasında ABD'de doğup gelişmesinden sonra 1960'lı yıllarda Avrupa'ya geçtiğini ve Avrupalı ülkeler tarafından uygulamalara başlandığ (Topuz, 1991).

Siyasal iletişim kavramının 1950'lerle beraber hem akademide hem de toplumsal hayatta önem kazanmasının nedeni, demokrasi kavramı ile yakından ilişkilidir. Zira bireylerin tercihlerinin hayatın her alanında önem kazanması, siyasal aktörlerin de yurttaşların özlemlerini dikkate alarak uygulama geliştirmelerine yol açmıştır (Wolton, 1991). Demokratikleşme anlayışı devlet yönetimindeki geleneksel kadroların parçalanarak, siyasal alanda değişiklik yaşanmasına neden olmuş, "sürecin siyasal düşünce alanına yansıması siyasal iktidarın halka dayandırılması görüşünü yaygınlaştırmıştır" (Tokgöz, 2010).

Özellikle İkinci Dünya Savaşından sonra "insan uğraşları giderek daha çok bilgi üretme ve toplamaya yöneldikçe, siyasal iletişim daha önemli bir konuma oturmuştur" (Tokgöz, 1986). Yeni biten savaş, demokrasi gibi görünen ancak demokrasi olmayan uygulamaların tehlikesi konusunda farkındalığı yükseltmiş, siyasilerin yurttaşlara ulaşmak için daha objektif 
metotları benimsemelerini gerekli kılmıştır. Siyasiler yurttaşların düşüncelerinden hareketle yeni politikalar üretme isteği içine girmiş, bu düşüncelere nesnel bir şekilde ulaşabilmenin yolunun bilim insanları ve kamuoyu araştırmalarından geçtiği anlayışı siyasal alana hâkim olmaya başlamıştır. Gelişmeler, Habermas'ın (2001) ifadesiyle "Büyük Bilim Dönemi"ni başlatmıştır. Bu dönem, sanayi-askeriye-üniversite işbirliğinin siyasal alana nüfuz ederek, politika üretme sahasına danışmanlar, uzmanlar ve bilim insanlarının da dâhil edilmesine zemin hazırlamıştır.

Bahsi geçen dönüşüm sadece siyaseti bilimselleştirmemiş, dördüncü kuvvet haline gelen medyanın da siyasette baskın hale gelmesi ile siyasal iletişim alanı yeni bir biçim almıştır. Gazete ve radyo ile başlayan, sinema ile devam eden ve nihayetinde televizyon ile taçlanan kitle iletişim araçlarının siyasal alana sirayeti, siyasal iletişimin bu alanlardaki önemini bu kez daha etkin bir biçimde kurgulamıştır. "1950'li yıllarda sadece bir seçim takvimi olarak işlev gören televizyon daha sonra liderlerin imajlarını kitlelere sunduğu, politikalarını anlattıkları, birbirleriyle rekabete geçtikleri bir alana dönüşmüştür" (Ware, 1996). Böylelikle "toplumsal ve teknolojik değişimlerin birleşmesiyle medya gittikçe çok daha güçlü siyasi bir aktör haline gelmiş ve bir bakıma siyasi sürece derinden nüfuz etmiştir" (Heywood, 2006).

Medyanın siyasal sürece derinden nüfuzu, siyasal iletişimin de medya mantığına uygun bir üslupla yeniden dizayn edilmesine neden olmuştur. Bu kez kitle iletişim araçlarındaki temsiller, olgulara değer yüklemesi yaparak ve özlemler sunarak bir ideolojiyi popüler bilince uyumlu kavramlara dönüştürebilme misyonuyla geniş kitleleri etkisi altına almaya başlamıştır (Swingewood, 1996). Süreç, siyasal aktörlerin medyadan etkin şekilde yararlanışı ile iktidar oluşlarını yakından ilişkili hale getirmiştir.

$\mathrm{Bu}$ aşamada lider imajı kavramı önem kazanmıştır. İmaj sözcüğü olumlu olabileceği kadar olumsuz da yansımaları olan bir kavram iken, imaj yönetimi pratikleri sonucunda ulaşılmak istenen itibar kavramı sadece olumlu bir anlamın taşıyıcısıdır. İtibar kavramı bir sürecin son aşamasıdır. Uzun vadeli kimlik ve imaj konumlandırma aşamalarının neticesinde itibar kavramı görünür hale gelmektedir. Bir bütünün tüm unsurları ile elde ettiği toplam değer olarak ele alınan itibar (Formburn, 1996) sözcüğü, planlı olarak izlenen itibar yönetimi sürecinde "toplum ile kurumlar arasındaki güvenin simgelerine dönüşmüş eylemler bütünü"ne (Kadıbeşegil, 2006) dönüşmektedir.

Dolayısıyla itibar yönetimi bir kişi ya da kurumun edimleri sonucunda hedef alıcıları tarafından atfedilen bir anlamın taşıyıcısıdır. "Bir kişi ya da örgütün genel değerler dizisine dayanan güvenilirliği, itimada layık oluşu, sorumluluğu ve yeterliliği hakkında çok sayıda kişisel ve kolektif yargıdan oluşmuş bir bütün olarak nitelenen (Demir, 2010) itibar yönetimi süreci çoğu zaman halkla ilişkiler alanında yapılan örgütsel çalışmalar temelinde ele alınsa da kavramın, ekonomi, hukuk, sanat, medya ve siyaset alanları ile de yakından ilintili olması sebebiyle halkla ilişkiler alanına bahsi geçen alanlarla birlikte çalışma şansı tanımaktadır.

\section{Yeni Siyaset Kavramı ve İtibar Yönetimine Sunduğu Açılımlar}

Çağın gerekliliği olarak siyasal iletişim medya mantığına göre yeniden dizayn edilirken, sahneye teknokratlar, danışmanlar, kamuoyu araştırma şirketleri, liderin özel hayatından alınan ilgi çekici unsurlar gibi geleneksel siyasette pek rağbet görmeyen kavramlar çıkmıştır. $\mathrm{Bu}$ yeni aktörler siyasal süreçten haberdar eden ama haber vermeyen; kitlenin canını sıkmayacak, dikkatini canlı tutacak düzeyde enformasyon sağlayan, temelde olumlu kimlik ve imaj konumlandırması yapmak amacını güden bir işlev görmeye başlamıştır. 
"Seçim kampanyaları 1960'larda 'new politics' olarak adlandırılan önce ABD'de başlayan ve siyasette uzmanlığa, teknik bilgiye, yaygın medya kullanımına önem veren 1970'lerden sonra Avrupa'da 1980'lerin başından itibaren de Türkiye'de gelişen bir eğilim içine girmiştir (Topuz, 1991). Bu yönelim ilk kez 1952 ABD Başkanlık seçimlerinde kendini gösterdiğinden kavram kimi kaynaklarda Amerikanlaşma olarak da anılmaktadır. 1952 Başkanlık seçimlerinde ABD'de ilk defa bir siyasi figürün reklamı kitle iletişim araçları vasıtasıyla seçmene ulaştırılmıştır. Eisenhower Kampanyası arka planında taşıdığı imaj konumlandırma anlamlarından ötürü "bir siyaset adamının sabun satma teknikleriyle pazarlandığı"(Donovan, 1992) bir seçim kampanyası olarak anılmıştır. Fakat Eisenhower'ın seçimleri kazanmasını takip eden süreç onu eleştiren siyasetçilerin özellikle televizyonda yer bulabilmek için reklam spotları çektirmek ve medya yardımıyla imaj inşa etmek için cesaretlenmesine yol açmıştır. Demokratik süreçte seçmenle kurulan iletişimin daha simetrik hale gelmesi idealini taşıyan uygulamalar, o güne değin seçmenin hakkında yüksek enformasyona sahip olmadığı siyasetçilerin, "insan tarafını" ön plana çıkarmaya yönelmiştir. Takip eden siyasal süreçte medyadaki, özellikle de televizyondaki imaj, aday gösterilmeyi sağlamada kilit ölçüt olmuş ve bir medya artisti olarak adayın imajı ve kimliği, parti programının önüne geçmiştir.

1960 ABD Başkanlık seçimleri ise yeni siyasetin başka bir unsurunu inşa etmesiyle dikkate değer bulunmaktadır. Başkan adaylarından Kennedy ile Nixon'ın televizyon ekranında canlı yayında her karşı karşıya gelmeleri, ülkenin heyecanla beklediği bir medya olayına dönüşmüştür. Bu durum siyasal düzlemde "tartş̧malar" (debates) döneminin de açılışını yapmıştır. Adaylar arasındaki tartışmaların şiddeti arttıkça izleyiciler de medya kuruluşları da vaziyetten memnuniyet duymaya başlamıştır. Zira her yüzyılda "şiddet ve çatışma genel geçer bir anlamda en evrensel haber değerini oluşturmakta" (İnal, 1996) bu da kitle iletişim araçları üzerinden yürütülen tartışmaların şiddetinin her geçen gün artmasına yol açmıştır. Yapılan kamuoyu araştırmalarına göre, başlarda epeyce geride olan Kennedy, medya üzerinden Nixon ile yürüttüğü atışmalar üzerinden yarattığı itibar ile seçimleri kazanmış, sürece dair "hiçbir şeyin, akıntının yönünü çevirmede televizyon kadar etkili olmadığını"(akt: Lang ve Lang, 1968) yorumunu yapmıştır.

On dokuzuncu yüzyılın ikinci yarısından itibaren yükselişe geçen yeni siyaset, siyasetin bilimselleşmesi, siyasetin kişiselleşmesi, siyasetin teknikleşmesi ve siyasetin medyatikleşmesi olarak adlandırılan dört bileşenden oluşmaktadır (Mancini and Swanson, 1996). Siyasetin bilimselleşmesi, kısaca sondaj, anket gibi nesnel yöntemler ile seçmenin istek ve beklentilerini belirlemeyi ifade etmektedir. Siyasetin bilimselleşmesi ile geleneksel parti tabanının yurttaşlarla yüz yüze gelerek şikâyetlerden haberdar olmasına gerek kalmamakta, kamuoyu araştırma şirketlerindeki profesyoneller bu işlemi hata payı daha düşük olacak şekilde gerçekleştirmektedir.

Siyasetin medyatikleşmesi, siyasi partiler ve liderleri tarafından medyada gündem belirlemenin her geçen gün önem kazandığı bir sürece işaret etmektedir. Bu yönelimin, detaylı siyasal içerikten yoksun konusuz siyasete yönelik ilgiyi artırdığı, dolaylı bir depolitizasyon süreci başlattığı ve hatta seçimleri partilerden ziyade medya üzerinden yürütülen kampanyaların kazandığı iddia edilmektedir.

Yeni siyasetin bir diğer unsuru olan siyasetin teknikleşmesi en dar haliyle siyaset alanına yeni bir meslek grubunu oluşturan siyasal danışmanların dâhil edilmesi olarak tanımlanmaktadır. Bir kısmını teknokratların oluşturduğu bu uzman grubunun görevi; global bir imaj yaratarak adayları birbirlerinden farklılaştırmak, nitel anketleri yorumlamak, 
nicel veriler üzerinden genel tanılar koymak, iletişim stratejisini konjonktürel olarak dizayn etmek, reklamcılık ve halkla ilişkiler tekniklerinin yardımıyla medya ile ilişkiler kurarak mesajların yayını ve algılanmasını kontrol etmektir (Bongrand, 1992).

Siyasetin kişiselleşmesi ise, politik liderin yönetilenlerin karşısına olabildiğince kişisel özelliklerinin vurgulanarak çıarılmasına işaret etmektedir. Kişiselleşen siyaset başlangıçta yurttaşların liderleri yakından tanıması amacıyla ortaya çıssa da, ulaştığ söylemlerden uzaklaşılarak siyasetin lider odaklı bir görünüme bürünmesine dolayısıyla 'politikaciların meşhurluğuna' (celebritization) (Olausson and Uggla, 2019) yol açmıştır. Kişiselleşen siyasette lider itibar oluşturmak için insanların duygularını yakalamak konusundaki kabiliyetlerini sergilemekte (Newman, 1999), bu aşamada liderin giyim tarzı, spor aktiviteleri, sanatsal zevkleri gibi kişisel özelliklerinin yanı sıra ailevi ve özel hayatına yönelik enformasyonun dolaşıma sokulması sağlanmaktadır. Böylelikle, medyadan aktarılan siyasetin kendisi de "eğlencelik olma, canlı ve parıltılı bir şov olma eğilimi" (Meyer, 2004) taşımaktadır.

Bahsi geçen bileşenlerin bir arada bulunması ile oluşan yeni siyaset 1950'lerle beraber siyasal alana girmiş, "siyasal partiler, parlamento, genel seçimler, oy verme bakımından 1970'li yıllardan başlayarak siyasal iletişimde giderek artış göstermiştir. Siyaset bir yandan medyatikleşirken, kamuoyu yoklamaları, piyasa araştırmaları, siyasal reklamlar, siyasal danışmanlar, halkla ilişkilerin rolü ve önemi toplumda önemli bir yer tutmaya başlamıştır (Tokgöz, 2008). Her ne kadar süreç içerisinde kullanılan tekniklerin gelişmesi ile lider cephesinden itibar yönetimi süreci daha kontrol edilebilir bir hal alsa da, kamu bu süreçte öngörülmeyen tepkiler vermeye başlamıştır. Örneğin, "televizyonda siyasal söylemlerin yayınlanması, haber bültenlerinde seçim sürecine yer verilmesi; hem siyasete olan ilgiyi artırmış, hem de siyasetçileri eğlence ve sanat dünyasının yıldızları kadar tanınmış bir hale getirmeyi başarmıştır(Smith, 1992). Kamusal anlamda bu yönelimin neden olduğu başlıca patolojinin parti bağları zayıflamış yüzergezer seçmene dönüşümün hızlanması olduğu söylenmektedir. Zira, başlangıçta seçmenin oy vereceği adayı daha yakından tanıması amacıyla dizayn edilen medya içerikleri, siyasileri 'show dünyasının bir figürü' haline dönüştürmeye başlamıştır. Süreçte izler kitle nezdinde siyasilerin tanınırlığı bilinirliği artarken, siyasal söylemleri flulaşmaya başlamıştır.

Bahsi geçen sürecin bir diğer patalojisi kamu nezdindeki gerçeklik algısı ile ilgidir. Siyasal enformasyona medya sunumları ile vakıf olan insanlar çoğu zaman medyadan aktarılan içerikleri gündemin önemli konusu olarak değerlendirmektedir. Bu nedenle de medyada yer bulmayan içerikler yokmuş gibi muamele görmektedir. "Görünenin aksine televizyon, gerçekliğin herhangi bir parçasını temsil etmekten çok, onu üretip yeniden inşa etmektedir. Televizyon kamerası ve mikrofon gerçeği kaydetmemekte sadece onu kodlamaktadır ve kodlama ideolojik gerçeklik duygusu üretmektedir" (Fiske, 1996). Bu aşamada haberin yayınlanmadan önce geçirdiği seçki sürecinden habersiz olan izleyici, dünyayı gerçekte olduğu ile aynı gördüğüne inanmaktadır (Meyer, 2004). Sartori (2004) bu süreci 'videopolitika' olarak adlandırmakta ve bireylerin siyasal alanda sunulan medya içeriklerini kuşkuya gerek bırakmayacak şekilde gerçek olarak algıladıklarını ifade etmektedir. Bu aşamada medya eli değen itibar yönetimi süreci kıymetlenmektedir.

Gelinen noktada liderin seçim dönemleri dışında da medya önündeki söylemleri, sergilediği davranışları ve kimlik ifadesi itibar yönetimi sürecinin başat uygulamalarına dönüşmektedir. Siyasi partilerin oluşumuna yol açan ideolojik farklılı̆̆ın çizgilerinin keskinliğini kaybetmeye başlaması, 'her kesime seslenen' (catch-all-party) partilerin özellikle yüzergezer seçmen 
tarafından tercih edilmesi siyasal aktörün, kitleyle kurduğu sempatik iletişimde sunduğu kimlik ifadesinin öneminin altını çizmektedir. Elektronik medyanın geleneksel kitle iletişim araçlarına oranla daha çok tercih edildiği günümüzde liderlerin kimlik inşası ve sunumu da ülke sınırlarını aşmaktadır. Politikada inşa edilen kimlik, davranışlar için taşıyıcı kiriş görevi görmekte, mümkün ve meşru olanı baştan şekillendirmekte ve bireylerin tercihlerini etkilemektedir (Wendt, 1996).

$\mathrm{Bu}$ anlamda günümüzde politik liderler sadece kendilerine oy veren seçmenlere odaklanmamakta, hedef kitlelerini dünyayı kapsayacak şekilde her geçen gün genişletebilmektedir. Uluslararası ilişkiler alanında kimliğin bir aktörün sahip olduğu kendine özgülük imajı olduğunu ifade eden Wendt (1999) siyasal aktörün davranışının sadece uluslararası alanda güç dağılımıyla değil, kimliklerin dağılımıyla da şekillenmekte olduğunun altını çizmektedir. Yeni siyaset anlayışının da vurguladığı üzere günümüzde ülkelerin dış ilişkilerdeki konumu, giderek lider kimliği üzerinden anlamlandırılmaktadır. $\mathrm{Bu}$ aşamada lidere düşen itibar yönetimi sürecinde kimliğinde en geniş kitle tarafından sempati uyandıracak unsurları bir araya getirmek olarak görülmektedir. Zira bu yönde sunulan "kimlik motivasyonel ve davranışsal eğilimler doğurmakta, ülke çıkarlarının şekillenmesinde aktif bir rol oynamaktadır (Wendt, 1999).

Gelişen teknoloji ve oluşan ihtiyaçlara cevap veren itibar yönetimi süreci hem ulus ötesi bir nitelik kazanmakta, hem de lider itibarı inşa etmek özelinde açılımlar sunmaktadır. İtibar yönetimi sürecinin lider odaklı açılımlar sunmasının bir gereklilik olduğunu ifade eden Fombrun (1996) bir toplum ne kadar iyi şeyler yapmış olursa olsun, liderinin toplum nezdinde akıllıca izlenim yaratmayan davranışlar sergilemesinin tüm toplumun itibarına yansıyacağını dillendirmektedir. Bu nedenle lider itibarı inşa etme modeli içinde yer alan uygulamalar, hedef kitlesi her geçen gün genişleyen siyasal figürlerin itibar yönetimini ele almakta ve süreci istenilen şekilde yapılandırmaktadır. Buna göre lider itibarı oluşturma süreci rehberlik, içeriksel öğrenme, politik beceri kimliği üzerinden inşa edilip, olumlu izlemin yaratacak ve beklenmeyen durumlara hızlı bir biçimde adapte edildiğini yansıtan davranışlar ile desteklenir ise etkili bir lider itibarı süreci gerçekleştirmek mümkün olmaktadır. Blass ve Ferris'in (2007) geliştirdiği lider itibarı modeline göre, öncül evrede liderin kanaat önderi olabilecek potansiyel ile sunulması bunun için de birçok farklı konunun içeriğine hâkim olabilecek bilgi birikimine sahip bulunması gerekmektedir. Takip eden politik beceri aşamasında liderin öncül aşamadaki kimlik sunumun pratiğe dökülmesi, toplumsal olaylar hakkındaki birikimini gerekli alanlarda ortaya dökmesi, toplumun eylem beklediği konularda hızlı bir biçimde reaksiyon alması gerekmektedir. Bu eylemlerde liderin hedef kitlesi üzerinde dürüst ve samimi bir izlenim yaratması önemli bir husus olarak değerlendirilmektedir. Liderin adaptasyon yeteneği yer aldığı etkinliklerde uyumlu olarak lanse edilmesi üzerinden karşılık bulmaktadır (Blass ve Ferris, 2007). Bunun için lider ve dâhil olduğu topluluklar arasında kişisel yakınlıklar, dostane görüntüler oluşturulmalıdır. Tüm bu aşamaların hassaslıkla yönetimi etkili bir lider itibarı oluşturmanın yolunu açmaktadır.

\section{Yöntem}

Çalışmada nitel araştırma yöntemlerinden içerik analizi kullanılmıştır. Metin kümesi içindeki anlamların ortaya çıkarılması amacıyla tercih edilen içerik analizi, haber metinlerindeki söylemlerin inşa ettiği anlamın ortaya koyulması amacını taşımaktadır (Büyüköztürk, 2017). İçerik analizi "söylemin görünen kolayca yakalanan sergilenmiş ve ilk 
bakışta algılanan içeriği yerine gizil, üstü örtülü içeriğini ortaya çıkarmayı sağlaması ile mesajda bireyi görünmeden etkileyen öğelerin belirlenmesine yönelik ikinci bir okuma" (Bilgin, 2006) özelliğine sahip olması nedeniyle çalışmanın amacı ile uygun bulunmaktadır.

\section{Araştırma Modeli}

İçerik analizinde, dokümanlardan elde edilen nitel araştırma verilerinin işlenmesi, verilerin kodlanması, temaların bulunması, kodların ve temaların düzenlenmesi, bulguların tanımlanması ve yorumlanması şeklinde dört aşama bulunmaktadır (Yıldırım ve Şimşek, 2006). Bu çalışmada da, ilk aşamada belirlenen tarama ölçütlerine göre kodlamalar yapılmış ve bu bağlamda temalara ulaşılmıştır. Ardından elde edilen veriler organize edilmiş, temalara göre gruplandırılmış ve uygun kategorilere yerleştirilmiştir. Analizin son aşamasında, elde edilen bulgular yorumlanmıştır.

\section{Evren-Örneklem}

$\mathrm{Bu}$ araştırmanın evrenini Hürriyet Gazetesi'nin 1 yıllık zaman diliminde (1 Ocak 2018 ile 1 Ocak 2019 tarihleri arasında) web sayfasında sunduğu haber içerikleri oluşturmaktadır. Dış politika haberlerine yoğun oranda yer vermesi ve comScore 2017 araştırmalarına göre Türkiye'nin ayda ortalama 174 milyon 250 bin tıklanma ile Similarweb 2018 araştırmalarının dünya üzerindeki tüm internet kullanıcılarının verilerini tek raporda sunan We Are Social Digital 2019 raporuna göre ise 145 milyon trafik ile en çok ziyaret edilen haber sitesi olması sebebiyle Hürriyet Gazetesi araştırmanın evrenini oluşturmaktadır.

Çalışma için dış politika haberleri Kanada Başkanı Justin Truedau ile ilgili olanlar ile sınırlandırılmış, bu doğrultuda hurriyet.com.tr üzerinden bir yıl boyunca yayınlanan tüm haberler değerlendirilmeye alınmış ve örneklemi oluşturmuştur. Çalışma için Hürriyet Gazetesi'nin 1 yıllık çevrimiçi ortamında erişilebilen tüm sayıları taranmış, seçkisiz yöntemle taranan haberler arasından Kanada Başbakanı Justin Trudeau'nun ismini içeren tüm haberler toplanarak bir haber havuzu oluşturulmuştur.

\section{Veri Toplama Araçları}

İlk tarama sonucunda 1 yıllık çevrimiçi yayınlarda Kanada Başbakanı Justin Trudeau'nun bulunduğu toplam 32 adet diş politika haberine ulaşılmıştır. Bütün haber metinleri incelendiğinde toplam olarak 25 tane haberin öznesinin Justin Trudeau olmasından ötürü çalışmaya dâhil edilmiştir. Bu aşamada örnekleme dâhil edilen 25 haber metni nitel kategorik içerik analizine tabi tutularak değerlendirilmiştir. Çalışmada yararlanılan web içerikleri Açıklamalar bölümünde sunulmuştur.

\section{Verilerin Toplanması ve Analizi}

Çalışmada yapılan kategorizasyon haber başlığı ve içeriğinin temel vurguları, çalışmanın ilk bölümünde detaylı olarak ele alınan Negrine ve Meyer'in (1999) işaret ettiği yeni siyaset unsurları ile Blass ve Ferris'in (2007) lider itibarı geliştirme modelinin kesiştiği noktaları ifade eden temalar üzerinden oluşturulmuştur. Kategoriler, liderin dış görünüşü, liderin aile hayatı, liderin davranışlarından oluşmaktadır.

Liderin dış görünüşü: Geleneksel siyaset yapma biçiminde, politikacıların resmi giyinmesi beklenen bir durumdur. Fakat yeni siyaset, politikacıların politik kimliğinin uzantısı olan 
ciddi görünümden ziyade rahat ve spor giyim tarzını öncelemekte, medya liderin verdiği böylesi görüntüleri daha çok tercih etmektedir. Bu kategori altında Kanada Başbakanının diş görünüşünün ana tema olarak yer aldığı haberler incelenmektedir.

Liderin aile hayatı: Geleneksel siyasal iletişimde politikacıların aile hayatları yahut özel hayatlarına yönelik herhangi bir enformasyon gerekli bulunmazken, yeni siyaset siyasal figürlerin siyasal arena dışında kalan özel hayatlarına yönelik haberleri, liderin seçmen tarafından daha "samimi" bulunacağı gerekçesiyle öncelemektedir. Çalışmanın bu kategorisini Justin Trudeau'nun aile hayatına yönelik temaların bulunduğu haberler oluşturmaktadır.

Liderin davranışları: Yeni siyaset anlayışı, politikacıların geleneksel siyasette olduğu gibi, katı, donuk ve hakim duruşundan ziyade daha içten ve "insansı" olarak yorumlanabilecek beklenmedik davranışlarının seçmen üzerinde tesirinin daha kuvvetli olduğunu iddia etmekte, kitle iletişim araçları böylesi durumlara daha yüksek oranda haber değeri atfetmektedir. Bu kategori altında Justin Trudeau'nun dış politika haberlerine yansıyan davranışları incelenmektedir.

\section{Bulgular}

\section{Liderin dış görünüşü}

Örneklemi oluşturan dış politika haberlerinde, Justin Trudeau'nun dış görünüşü temelde durmakta, metinlerdeki ifadeler bu kaide üzerinde yükselmektedir. Liderin dış görünüşünü vurgulayan haberler arasında en çok onun giyim tarzına yönelik haberler bulunmaktadır. Giyim tarzına yönelik haberler içerisinde ise en fazla liderin çoraplarından bahsedilmektedir. Öyle ki lider Dünya Ekonomik Forumu, ya da G7 zirvesinde bulunduğunda yaptığ konuşmalardan ziyade çoraplarıyla haber olmaktadır. "Kanada Başbakanı Trudeau'nun ördekli çorapları Davos'a damga vurdu", Trudeau'nun renkli çorapları katıldı̆̆ı törene damga vurdu"(Açıklama 1), "Herkes o detaya takıldı, çorapları konuşmasının önüne geçti" (Açıklama 2), ana başlıklarıyla paylaşılan haberlerde, lider her ne kadar ekonomik büyüme, dini hoşgörü, yoksulluk, girişimcilik gibi konulara yönelik konuşmalar yapmış olsa da metinlerde bu konuşmalar ya hiç yer almamakta ya da tek cümlelik bir detay olarak sunulmaktadır. Liderin Star Wars karakterleri ile bezeli yahut çizgi film kahramanlarının görsellerini taşıyan çoraplarının, sosyal medyada da yoğun ilgi gördüğünün altının çizildiği haberlerde liderin siyasal söylemleri yerine çorap tercihinin yarattığı etki, seçtiği karakterlerin ne anlama geldiği gibi eğlencelik konulardan ise detaylı bir biçimde bahsedilmektedir. Resmi ortamlarda takım elbise giymek tüm liderler için bir protokol gerekliliğidir. Dünya liderlerinin katıldığı zirvelere yahut ülke için önemli olan anma günlerine yarı resmi ya da resmi olmayan kıyafetlerle katılmak seçmenin nezdinde liderin nezaketsizliği olarak yorumlanma potansiyelini taşımaktadır. Fakat çorap seçimindeki marjinallik liderin renkli kişiliğinin yansıması olarak aktarılmakta, lider samimi ve içten bulunmaktadır.

Trudeau giydikleri kadar giymedikleri ile de sıklıkla dış politika haberleri arasında yer alan bir liderdir. "Kanada Başbakanı'nın üstsüz görüntüleri internete bomba gibi düştü", Başbakandan ziyade 'Pop Star' gibi" (Açıklama 3) başlıklarıyla sunulan haberlerin içeriğinde, liderin ormanda üstsüz koşu yaparken küçük bir çocukla çektiği selfie ya da kumsalda mayoyla elinde sörf tahtasıyla verdiği görüntülerden oluşan görseller galeride tek tek sergilenmektedir. BBC, İngiliz Independent gazetesi gibi saygın kuruluşların referansı ile 
sunulan haberlerde liderin bir Başbakandan çok tüm dünyada ilgi gören ve hayranları bulunan bir "pop star" gibi olduğundan bahsedilmektedir.

Lider Trudeau'nun Başbakan olmadan önceki yıllarında çekilmiş fotoğrafları da BBC tarafından sunulup, Anadolu Ajansı tarafından hürriyet.com.tr de yer alan haberler arasındadır. Belirsiz aralıklarla servis edilen haberler ve fotoğrafların, sosyal medyada en çok konuşulan konular arasında yer aldığı için verildiği ifade edilen haberlerde galeri biçiminde başkanın çocukluk ve gençlik fotoğrafları sergilenmektedirł. Benzer şekilde aralıklı zamanlarda başkanın gençlik fotoğrafları sosyal medyadan alınan yorumlar eşliğinde sergilenirken "yakışıklılığıyla gündeme gelen başkan" ifadeleri bulunmaktadır (Açıklama 4). Başkanın yakışıklılığı temeli üzerinde yükselen haberler arasında Justin Trudeau'nun Beyaz Saray'da Donald Trump'la olan görüşmesi bir detay olarak yer alırken, haberde asıl vurgu, Trump'ın kızı Ivanka Trump'ın ilk kez Beyaz Saray'da bir oturuma katıldı̆̆ı üzerine kurgulanmaktadır(Açıklama 5). Ivanka Trump'ın Trudeau'ya beğeni dolu bakışlarını yönelttiği fotoğraflar ile sunulan haberde Ivanka Trump'ın bu toplantıya katılabilmek için babasına ettiği israrların da altı çizilmektedir. Benzer şekilde Trudeau'nun Almanya'da Merkel ile yaptığı diplomatik görüşme de, "Trudeau'nun yeni hayranı Merkel" alt başlığı ile sunulmaktadır(Açıklama 6). Basına kapalı gerçekleşen görüşmeden fotoğrafları içererek galeri formatında servis edilen haberde Merkel'in Trudeau'ya yönelttiği bakışlara odaklanılmakta, bu bakışların sosyal medya gündemini sarstığı ifade edilmektedir. Haberde Trudeau'nun yine "yakışıklılığıyla gündemde olan" sıfatıyla sunulması ve Cambridge Düşesi Kate Middleton ve ABD Başkanı Donald Trump'ın kızı Ivanka Trump ile de benzer karelerin yakalandığından bahsedilmesi dikkat çekmektedir(Açıklama 7). Medya içeriklerinde Trudeau bütünüyle yakışıklılık sıfatıyla örtüştürüldügünden, İspanya'nın yeni Başbakanı seçilen Pedro Sanchez'in haberi, "Trudeau'ya Rakip Çıktı" başlığı ile verilmekte, içerikte Sanchez'in ülkemizdeki sosyal medya kullanıcıları tarafından 'Biscolata erkeği'ne benzeterek Trudeau'ya rakip geldiğinin söylendiği ifade edilmektedir (Açılama 8).

Kanada'nın G7 zirvesine ev sahipliği yaptığı bir başka haber ise başkan Trudeau'nun Fransa Cumhurbaşkanı Emmanuel Macron'la basın toplantısı yaptığında kaşlarının durumuna odaklanılarak sunulmaktadır. Haberde ne G7 zirvesinin, ne de Macron ile yapilan basın toplantısının detaylarından bahsedilmekte, Trudeau'nun kaşlarının yapıştırma olup olmadığına yönelik kaşlarının yakın çekimle farklı açılandan sunulmuş fotoğraflarına yer verilmekte, haber içeriğinde liderin yakışıklılığının altı bir kez daha çizilmektedir. Ayrıca sosyal medyada "trend topic"(tt) olan başkanın kaşları konusuna yönelik eğlenceli twitler de haberde paylaşılmaktadır.

\section{Liderin aile hayatı}

Siyasi figürün aile hayatını odağa alan haberlerin neredeyse tümünün teması anlam Trudeau'nun ne kadar sevecen ve eğlenceli bir aile babası olduğu yönünde inşa edilmektedir. Haberin başlığı her ne kadar "Kanada Başkanı Justin Trudeau'nun öyle bir görüntüsü çıktı ki!" olsa da habere tıklandığında içinden Justin Trudeau'nun çocuklarıyla beraber evinin duvarlarını boyadığı fotoğraflar sergilenmektedir(Açıklama 9). Başka bir haberde ise Başbakanın yine ailesi ile neşe içinde Hindistan'a özgü yöresel elbiseler giyinmiş halleri sergilenmektedir. Liderin eşinin ve çocuklarının isimlerine ayrı ayrı yer verilen haber, ailenin eğlenceli görüntüleri eşliğinde sunulmaktadır(Açıklama 10). 
Trudeau her ne kadar diplomatik ilişkilerde kadınlar tarafından etkileyici bulunduğu için siyasiden ziyade magazinel haberler yapılmasına imkan verse de, sosyal medya hesabında iyi bir aile babası, eşine aşık bir erkek olarak konumlandırılmaktadır. Dolayısıyla liderin aile yaşamına yönelik yapılan haberler de bu minvaldedir. AA'nın referansıyla sunulan haberde Trudeau'nun eşinin doğum gününde twitterdan onunla öpüştüğü bir fotoğrafi paylaşması ve "Harika bir anne ve ne kadar şanslıyım ki en yakın dostum olan karıcığım, iyi ki doğdun. Beraber macera dolu bir yıl daha geçirelim." sözlerini yazması ele alınmaktadır. Başkanın bir diğer twitter paylaşımında Müslümanların Kurban Bayramını kutlarken "Ailemiz adına, eşim Sophie ve ben, Eid al-Fitr'i (Ramazan Bayramı) kutlayan herkese en içten dileklerimizi sunuyoruz. Eid (bayram) Mübarek" ifadelerini kullanmasına dikkat çekmektedir(Açılama 11). BBC tarafından servis edilen haberin devamında geçmiş yıllarda Trudeau'nun eşi Sophie Grégoire Trudeau'nun Le Soleil gazetesine verdiği röportajda 'first lady' olarak her yere yetişemediğini, üç çocuk ve Başbakan bir kocaya yetişmek için yardıma ihtiyacı olduğunu söyleyerek tartışmalara neden olduğu konuşmaya da atıf yapılmaktadır.

\section{Liderin davranışları}

Justin Trudeau geleneksel anlamda insanların zihninde bulunan politikacı sterotiplerinin dışında kalan davranışlarla tüm dünyayı şaşırtmaktadır. Bu davranışlarının başında liderin sosyal medya hesabından yapılan paylaşımlar gelmektedir. Trudeau'nun sosyal medya hesapları diğer birçok siyasal aktör gibi "ciddi işler" yerine çocukluk ya da gençlik fotoğrafları paylaşmak, liderin ailesiyle özel anlarını ifşa etmek gibi içerikler sunmaktadır. $\mathrm{Bu}$ nedenle de sadece Kanada halkı tarafından takip edilmemekte, dünyanın pek çok farklı kesiminden takipçi bulmaktadır. Liderin sosyal medya hesaplarından yapılan paylaşımlar da birçok gazete ve internet sitesi için haber kaynağı oluşturmaktadır. Dünyanın önemli devlet adamlarından "Kanada Başbakanı Justin Trudeau, Twitter'dan müzik listesini paylaştı" veya "PM Mix' adlı 39 parçalık bir liste yayınlayan Trudeau, 'Bu yaz ne dinliyorum? Ne dinlemeliyim? Spotify'daki PM Mix listemi kontrol edin' yazıp linki paylaştı." (Açıklama) gibi başlıklarla servis edilen haberlerde başkanın en sevdiği şarkılar sıralanmaktadır. Esasen müzik listesi paylaşımı ile gündem olan ilk isim Trudeau değildir. Zira Trudea'dan yaklaşık 5 yıl önce ilk kez Spotify'da ABD Başkanı Obama'nın müzik listesini yayınlanmış ve sonraki dönemde de rutin olarak yayınlamaya devam etmiştir. Hatta eşi Michael Obama'nın fitness müzikleri listesini dahi Obama'nın sosyal medya hesabından yayınlamıştır. Bunlar yeni siyaset anlayışının çıkış noktası olan ABD'de dahi ilk yayınlandığında günler boyu gündemde kalmış olaylar olarak bulunmaktadır. Takipçileri ile yakın ilişki kurarak duygudaşlık halini yaratmak isteyen Trudeau'nun müzik paylaşımının yer aldığı haberde "..orijinal liste, liderin sevenleri ve onu takip etmek isteyenler için büyük şans. Bu şansa Ronald Reagan'ın başkanlığı döneminde yaşayanlar sahip değildi! Reagan benzer bir durumu yapmak isteseydi yapabileceği tek şey gazetecilere odasındaki plakları tek tek göstermek olurdu" ifadeleri kullanılarak esasen bu çalışmanın da konusu olan yeni siyaset anlayışının uygulamadaki geçerliğini ortaya koymaktadır.

Dış politika haberlerinde imajı beklenmedik davranışlar ile birlikte inşa edilen Trudeau, kimi zaman yüzmek için denize giren bir çocuğun arkasında belirip fotoğraf karesine girmekte, kimi zaman doğa yürüyüşü yapan bir ailenin karşısına çıkmakta, kimi zaman şakalaşıp eğlenen gençlerin arasına karışarak haber olmaktadır. Bu davranışları başkanın "içimizden biri" gibi olduğu intibasını sağlamlaştırırken, geleneksel siyasetin öncelediği "yurttaşlar 
siyasi figürü sadece siyaset yaparken görmeyi tercih eder" anlayışını da kırmaktadır. Trudeau'nun bu tesadüfî görünen davranışları çoğu zaman medya mantığına göre dizayn edilmiş olaylardır. Örneğin, Vancover şehrinde mezuniyet fotoğrafı çektiren öğrenci topluluğunun arasına koşu yaparak giren Trudeau'nun bu anının fotoğrafını çekerek "Vancover'da balo sezonu" adı ile sosyal medya hesaplarında paylaşan kişi Trudeua'nun resmi fotoğrafçısı Adam Scotti'dir. Her ne kadar bu olay medyada Trudeu'nun sahilde sabah koşusuna çıktığı anda rastlantısal bir şekilde gerçekleşmiş gibi sunulsa da (Açıklama 12). esasen resmi fotoğrafçı (uzman) eşliğinde sabah koşusuna çıkmak planlanmış bir olaydır ve siyasetin teknikleşmesi emarelerini taşımaktadır.

Benzer şekilde başkan Trudeau'nun NATO zirvesinde tüm kameraların önünde zirvenin ev sahibi Belçika Başkanı Charles Michel'den önce, başkanın eşi first lady ile el sıkışarak başkan Michel'e şaka yapması uzun süre medyayı meşgul eden bir olay olmuştur(Açıklama 13). Dünya basınının önünde yapılan bu şaka esasen doğal olmaktan öte planlanmış bir eylemdir ve yeni siyaset anlayışının gerekliliğidir. Trudeau'nun, 43. G7 zirvesinde tüm liderler kendi aralarında sohbet ederken dışarıda kaldığı ve sohbete dâhil olmak için yavaş yavaş liderlere yanaşırken girdiği komik şekillerin danışmanları tarafından medyaya servis edilmesi(Açıklama 14) yine benzer bir teknikle uygulanmakta, Trudeau'nun sosyal medyada en çok konuşulanlar arasına girmesine yol açmaktadır.

Başka bir haberde Kanada milli marşında bulunan cinsiyetçi ifadelerin (bütün oğulların emrinde) Kanadalılarda yarattığı rahatsızlıktan ve 30 yıldır marşın değiştirilmesi için aralıklı zamanlarda meclise önergeler sunulmasına rağmen sonuç alınamadığından bahsedilmektedir. "Kanada'nın kadın - erkek eşitliğine son derece önem verdiğini her fırsatta yineleyen genç Başbakanı Justin Trudeau marşın değişmesine tam destek verdiği"(Açıklama 15) ve sonunda kabinesini kurarken gözettiği kadın-erkek bakan eşitliğine benzer bir uygulamayı, bu kez de ülkenin milli marşı "O Canada" üzerinde yaptığı haberde aktarılmaktadır. Bu bağlamda haberde Trudeau hem sorun çözücü, duyarlı ve sözünü tutan kişilik özellikleri ile hem de ülkenin taşıyıcı lokomotifi olarak konumlandırılmaktadır.

Trudeau'nun diş politika haberlerinde yer bulan davranışları arasında kameralar önünde sıklıkla gözyaşlarını tutamaması da bulunmaktadır. Kanada'nın Quebec City kentinde İslam Kültür Merkezi Camisi'ne yapılan terör saldırısında hayatını kaybedenler için düzenlenen törende kameralar önünde gözyaşlarını sergileyen Trudeau(Açılama 16), başka bir seferinde $\mathrm{ABD}$ askerlerinin anıt mezarında ağladığı görüntüler ile medyada yer bulmaktadır(Açıklama 17). Dini ya da milli olaylarda gözyaşlarını sergileyen başkan, Gord Downie isimli rock müzik şarkıcısı hayatını kaybettiğinde de benzer şekilde kameraların karşısına geçerek, gözyaşları içinde duygusal bir konuşma yapmıştır(Açılama 18) Tüm bunlar yeni siyaset anlayışının altını çizdiği üzere siyasal aktörün toplum nezdinde sempati kazanmasına yol açan olaylar olarak değerlendirilmektedir.

Trudeau'nun siyasi atışmalar (debates) durumunda takındığı tavır da yine kimliğinin konumlandırıldığ1 sempatiklik öğesi temelinde yürütülmektedir. Huawei Mali İşler Direktörü Mıng Vancou'nun Kanada'da tutuklanması ile Çin ve Kanada hükümetleri arasında oluşan kriz Çin'in de karşılık olarak iki Kanadalıyı gözaltına alması ile büyürken, Trudeau konuyu "Bu, dünyadaki en büyük iki ekonominin, Çin ve Amerika Birleşik Devletleri'nin birbirleriyle kavga etmeye başladıkları zaman yaşanan durumlardan biri. İki ülkenin aralarında yükselen ticaret savaşı, Kanada'da ve potansiyel olarak tüm küresel ekonomide her türlü istenmeyen sonuçlara sahip olacak. Bu konuda çok endişeliyiz." (Açılama 19) ifadeleriyle sükunet içinde ele almaktadır. Aynı konu ile ilgili düzenlenen 
basın toplantısında, Trudeau, Kanada mahkemelerinin bağımsız davrandığını ve davanın siyasi bir karar olmadığını ülkesinin süreçlerinin bağımsızlığına saygı duyduğundan konuyla ilgili diplomatik hiçbir görüşme yapmadığını ifade etmektedir(Açıklama 20). Benzer bir sempatik diplomatik tavir 2018 G-7 zirvesinden sonra Trump'ın Trudeau'nun düzenlediği basın toplantısındaki vergilere yönelik sözlerine cevaben kullandığ1 "Bu davranışı Kanada halkına pahalıya mal olacak. Trudeau'nun dersini aldığını düşünüyorum" sözlerine (Açıklama 21) nasıl bir karşılık vereceği sorulduğunda "Mesajımız kibar olacak. Kanada, ABD Başkanının kum torbası değil"(Açılama 22) açıklamalarıyla kendini göstermektedir.

Trudeau ülke sorunlarını aşarak dünya sorunlarına da parmak basan bir lider imajını sabitlerken yine sempatik bir yöntem kullanmaktadır. Suudi Arabistan asıllı bir kadın Kanada vatandaşı ve ona eşlik eden iki kadının Suudi Arabistan'da tutuklanması üzerine iki ülke arasında başlayan kriz, Suudi Arabistan'ın Kanada Hükümeti ile tüm ticari ilişkileri dondurarak büyükelçisini geri çağırdığını ilan etmesiyle zirve noktasına ulaştığında, Trudeau'nun düzenlediği basın toplantısında kullandığ alanda insan haklarıyla ilgili güçlü ve açık bir şekilde konuşmaya devam edecektir. Kanada'nın hedefi Suudi Arabistan ile kötü ilişkilere sahip olmak değildir. Suudi Arabistan ile sağlam ilişkilere sahip olmak istiyoruz. Suudi Arabistan, dünyada belirli bir önemi olan ve insan hakları konusunda ilerleme kaydeden bir ülke ancak biz de dünyanın her yerinde var olan zorlukların altını çizmeye devam edeceğiz" ifadeleriyle yumuşamıştır. (Açıklama 23). Yaşanan bu krizden aylar sonra gerçekleşen Kaşıkcı Cinayeti sonrası G-20 zirvesinde Suudi Arabistan Veliaht Prensi Muhammed bin Selman ile yanyana görüntü veren Trudeau Kanada'nın resmi yayın kuruluşu CBC televizyonuna yaptığı açıklamada, Veliaht Prense tutuklanan kadın aktivistleri hatırlattığını, ayrıca Kaşıkçı cinayeti ile ilgili daha iyi yanıtlara ihtiyaç olduğunu söylediğini açıklamıştır(Açıklama 24).

\section{Tartışma ve Sonuç}

$\mathrm{Bu}$ çalışmada iletişim, dış politika, medya ve siyaset alanları arasındaki etkileşim itibar yönetimi ekseninde ele alınmıştır. Bu nedenle çalışmada ilkin, siyasal iletişim ontolojik düzlemde değerlendirilmiş, peşinden alandaki trendler ortaya konmuştur. İletişim teknolojisindeki gelişmeler, toplumsal mobilite, demokratik ve hukuki dönüşümlere bağlı olarak siluet değiştiren siyasette, sahneye çıkan yeni aktörler ve uygulamalar temelinde yapılan değerlendirmeler, yeni siyaset eğiliminin her geçen gün belirgin hale gelmekte olduğunu teorik anlamda söylemeyi mümkün kılmıştır. Bu temel üzerinde yükselen çalışmanın devamında ülkemizde üzerinde fazla çalışılmamış bir kavram olan yeni siyasetin iletişimsel yansımaları, kavramın oluşumu, özellikleri, gerekliliği, patolojileri ve ulaşabileceği boyutlar çerçevesinde irdelenmiş, bu kavramın halkla ilişkilerde itibar yönetimine sunduğu açılımlar değerlendirilmiştir.

Çalışmanın ikinci bölümünde Kanada Başbakanı Justin Trudeau'nun uluslararası medya dolayımıyla yapılan imaj konumlandırılması üzerinden yeni siyaset nosyonu somutlanmaya çalışılmıştır. Bunun için Türk medyasında Başbakanın adının geçtiği haberler içerik analizine tabi tutulmuş, itibar yönetimi temelinde yeni siyaset eğilimi göstergelerinden oluşan kategoriler yardımıyla görünür kılınmıştır. Bulgular neticesinde, Kanada Başbakanı Justin Trudeau'nun kimlik konumlandırmasının birincil olarak sosyal medya üzerinden yapılmakta olduğu ortaya çıkmaktadır. Bu durum Başbakanın hedef kitlesinin sadece 
ülkesindeki seçmenler olarak kısıtlamamakta, tüm dünyadaki internet kullanıcılarını kapsayacak genişlikte bir itibar yönetimi yürüttüğünü zikretmeyi mümkün kılmaktadır.

Başbakanın Türk medyasında yer bulan haberlerinin içerikleri büyük oranda OTTAWA, CBC gibi Kanada menşeli medya kuruluşları tarafından ulus ötesi medya kuruluşlarına ulaştırılmakta, bu kuruluşlar tarafından haberler tüm dünyaya servis edilmektedir. Dolayısıyla itibar yönetimi sürecinin çıkış noktası haber çerçevelenmesini yapan bu kuruluşlar olarak bulunmaktadır. Türkiye'ye AA ve DHA tarafından sunulan haberler yoğun olarak Başbakanın ideolojik söylemlerinden yahut siyasal edimlerinden azade, şöhret sahibi popüler bir kişilik olarak kurgulandığı içeriklere sahiptir. Yakışıklılığı, elbiseleri, aile hayatı, boş zaman aktiviteleri, özel zevkleri üzerinden inşa edilen imaj ile Başbakanın haberleri sıklıkla fotoğraf galerisi formatında sunulmaktadır. Bu haliyle Türk medyasında dünya haberleri kategorisinde sunulan Trudeau içerikleri diplomatik olmaktan öte magazinel özellik taşımakta, haberler siyasetin kişiselleşmesinin somut birer örneği olarak ortaya çıkmaktadır.

Dünya siyasetinde önemli konumlarda bulunan Angela Merkel, Ivanka Trump, Kate Middleton gibi kadınların Trudeau'ya yönelik ilgisinden birçok haberde doğrudan ya da dolaylı olarak söz edilmektedir. Basına kapalı gerçekleşen toplantı ve akşam yemeklerinde çekilen fotoğrafların medyaya sonradan servis edilmesi fotoğraf seçiminin Trudeau ve ekibi tarafından yapılarak, bahsi geçen kadınların hayranlık dolu bakışlarının yansıtacak şekilde seçildiğini göstermektedir. Haber metinleri ile desteklenen fotoğraflar üzerinden Trudeau'nun karizması ile Kanada hükümetinin Almanya, Amerika ve İngiltere hükümetleri ile samimiyet temelli ilişkilere sahip olduğu mesajı verilerek güvene dayalı bir itibar yönetimi anlayışı sürdürülmektedir.

Analiz neticesinde ortaya çıkan başka bir sonuç, Trudeau'nun çoğu zaman tesadüfi ya da doğaçlama gibi görünen eylemlerle medyada yer bulmasıdır. Bu eylemler beklenmedik yerlerde ve zamanda gerçekleştiğinden medyanın rağbet ettiği, haber değeri yüksek eylemlere dönüşmektedir. Bu durum Başbakanın medya içeriğini belirlemesine ve hatta sosyal medyada haftalar boyu gündemde kalmasına yol açmakta, siyasetin medyatikleşmesinin örneğini oluşturmakta, liderin itibar yönetiminde aranan adaptasyon yeteneğinin de altı çizilmektedir.

Başkanın itibar yönetimi sürecinde görselliğe verdiği önem onu bu konuda profesyonel destek almaya itmekte bu da yeni siyasetin diğer unsurlarından siyasetin bilimselleşmesi ve teknikleşmesine yönelik içeriklere rastlanmasına yol açmaktadır. Başbakanın sabah doğa yürüyüşüne çıarken ya da akşamüzeri nehir kıyısında gezinirken resmi fotoğrafçısının yanında olması, Trudeau insanların karşılarına çkıp onları şaşırtırken, resmi fotoğrafçının olup biteni fotoğraflayarak sosyal medya hesaplarından paylaşılmasını sağlaması siyasetin teknikleşmesine örnek oluşturmaktadır. Diğer taraftan Trudeau'nun Pew araştırma şirketine yaptırdığı kamuoyu araştırmasında Trump'a yönelik güvenin çok düşük olduğunun ortaya çıkmasından sonra, ABD askerlerinin anma törenine yağmur gerekçesiyle katılmayan Trump'a yönelik imalı ifadeler kullanmasının ardından yapılan yeni ankette Trudeau'nun Trump'la geriliminin, partisinin Muhafazakârların önüne geçmesine yol açtığının ifade edilmesi yahut Trudeau'nun "https://www.surveymonkey.com/r/3X66Z59" adresinden yapılan anket ile kamuoyunun nabzını tutması siyasetin teknikleşmesine örnek olarak gösterilebilmekte, aynı zamanda güven unsuru üzerinden yürütülen itibar yönetiminin altını çizmektedir. 
Sonuç olarak Kanada Başbakanı Justin Trudeau'nun dış politika edimleri, Reuters, BBC, Independent gibi ulus ötesi medya kuruluşları tarafından tüm dünyaya ulaştırılmakta, bu içeriklerde liderin kimliği samimi, dinamik, şaşırtıcı, şakacı ve çekici unsurlar üzerinden konumlandırılmaktadır. Siyasetin kişiselleşmesi ve medyatikleşmesi nüvelerini taşıyan bu itibar yönetimi süreci, ülkemizde Trudeau'nun sempatik ve sorun çözücü bir lider imajı ile medyada yer bulduğunu ortaya çıkarmaktadır.

\section{Kaynakça}

Bilgin, Nuri (2006). Sosyal Bilimlerde İçerik Analizi: Teknikler ve Örnek Çalışmalar, Ankara: Siyasal Kitabevi, 1.

Blass, Fred R., and Gerald R. Ferris (2007). Leader Reputation: The Role of Mentoring, Political Skill, Contextual Learning and Adoptation, Human Resource Management, 5-19.

Bongrand, Michel (1992). Politikada Pazarlama, İstanbul: İletişim Yayınları, 21-22.

Büyüköztürk, Şener, Çakmak, E. K., Akgün, Ö. E., Karadeniz, Ş., ve Demirel, F. (2017). Bilimsel Araştırma Yöntemleri, Ankara: Pegem Yayınları, 2-62.

Demir, Filiz (2010). Kurumsal İtibar Ölçümünde Kişiselleştirme Metaforu, Review of Social Economic and Business Studies, 247-262.

Donovan, Robert, Scherer Ray (1992). Unsilent Revolution: Television News and American Public Life, New York: Wilson Center \& Cambridge University Press. 46.

Fiske, John (1996). İletişim Çalışmalarına Giriş, Ankara: Bilim Sanat Yayınları, 95.

Fomburn Charles J,. (1996). Reputation: Realizing Value from the Corporate Image, Boston: Harvard Business School Press, 35-55.

Habermas, Jürgen (2001) İletişimsel Eylem Kuramı, (Çev. M. Tüzel), İstanbul: Kabalcı Yayınevi, 75.

Heywood, Andrew (2006). Siyaset, (Çev.: B. B. Özipek), Ankara: Adres Yayınları, 294.

İnal, Ayşe (1996). Haberi Okumak, İstanbul: Temuçin Yayınları, 124.

Iyengar, Shanto (1997). Do The Media Govern?, London: Sage Publications, 124.

Kadıbeşegil, Salim (2006). İtibar Yönetimi, İstanbul: MediaCat Kitapları, 30.

Lang, Gladys E., Lang, Kurt (1968). Politics and Television, Chicago: Quadrangle Books, 216.

Mancini, Paolo and Swanson, David (1996). Politics, Media, and Modern Democracy: Introduction, in Politics, Media, and Modern Democracy: An International Study of Innovations in Electoral Campaigning and Their Consequences (eds: Mancini and Swanson), Praeger Publishers, 1-26.

Meyer, Thomas (2004). Medya Demokrasisi: Medya Siyaseti Nasıl Sömürgeleştirir?, İstanbul: İş Bankası Yayınları, 79, 90-93.

Newman, Bruce (1999). The Mass Marketing of Politics, London: Sage Publications, 90.

Negrine, Ralph M., (1996). The Communication of Politics, London: Sage Publications, 148. 
Olausson, Ulrika and Uggla Ylva (2019). Celebrities Celebrifying Nature:The Discursive Construction of the Human-Nature Relationship in the 'Nature Is Speaking' Campaign, Celebrity Studies, 1-18.

Sartori, Giovanni (2004). Görmenin İktidarı (Çev.: B. Ulusoğlu Darn, G. Batuş), İstanbul: Karakutu Yayınlar1, 54.

Smith, Chris (1992). What Vote? Your Independent Guide to the General Election, London: Sage, 79 .

Swingewood, Alan (1996). Kitle Kültürü Efsanesi, (Çev: A. Kansu), Ankara: Bilim ve Sanat Yayınları, 132.

Tokgöz, Oya (1986). Siyasal İletişim, Türkiye'de Sosyal Bilim Araştırmalarının Gelişimi, (Der.:S. Atauz), Türk Sosyal Bilimler Derneği Yayınları, 4, 97, 103.

Tokgöz, Oya (2008). Siyasal İletişimi Anlamak, Ankara: İmge Kitabevi Yayınları, 419.

Tokgöz, Oya (2010). Seçimler, Siyasal Reklamlar ve Siyasal İletişim, Ankara: İmge Kitabevi Yayınları, 522.

Topuz, Hıfzı (1991). Siyasal Reklamcılık: Dünyadan ve Türkiye'den Örneklerle, İstanbul, 4, 179.

Ware, Alan (1996). Political Parties and Party Systems, London: Oxford University Press, 289-290.

Wendt, Alexander (1996). Identity and Structural Change in International Politics, (ed. Y. Lapid ve F. Kratochwil), The Return of Culture and Identity in IR Theory, Boulder, London: Lynne Rienner Publishers, 47-64.

Wendt, Alexander (1999). Social Theory of International Politics, Cambridge: Cambridge University Press, 224-231.

Wolton, Dominique (1991). Medya, Siyasal İletişimin Zayıf Halkası, Birikim Dergisi, Sayı:30, Ekim, İstanbul, 51-58.

Yıldırım, Ali ve Şimşek, Hasan (2005). Sosyal Bilimlerde Nitel Araştırma Yöntemleri, Ankara: Seçkin Yayınları.

\section{Açıklamalar}

1."Trudeau'nun renkli çorapları katıldığı törene damga vurdu", 01.05.2017, http://www.hurriyet.com.tr/dunya/trudeaunun-renkli-coraplari-katildigi-torene-damga-vurdu40443791 (Erişim tarihi 13 Mart 2019)

2."Herkes o detaya takıldı! Çorapları konuşmasının önüne geçti", 21.09.2017, http://www.hurriyet.com.tr/dunya/herkes-o-detaya-takildi-coraplari-konusmasinin-onune-gecti40585901 (Erişim tarihi 18 Şubat 2019)

3."Kanada Başbakanı'nın üstsüz görüntüleri internete bomba gibi düştü!", 08.08.2017, http://www.hurriyet.com.tr/dunya/kanada-basbakaninin-ustsuz-goruntuleri-internete-bomba-gibidustu-40185527 (Erişim Tarihi 28 Ocak 2019). 
4."Kanada başbakanı Justin Trudeau'nun gençlik fotoğrafları olay oldu", 02.03.2017, http://www.hurriyet.com.tr/galeri-kanada-basbakani-justin-trudeaunun-genclik-fotograflari-olayoldu-40382889 (Erişim tarihi 12 Şubat 2019).

5."Ünlü siyasetçiyi tanıyabildiniz mi? Sosyal medya yıkıldı", 01.03.2017, http://www.hurriyet.com.tr/galeri-unlu-siyasetciyi-taniyabildiniz-mi-sosyal-medya-yikildi-40381455 (Erişim tarihi 12 Şubat 2019).

6."Ivanka Trump'tan Beyaz Saray'da bir ilk", 14.02.2017, http://www.hurriyet.com.tr/galeri-ivankatrumptan-beyaz-sarayda-bir-ilk-40365962 (Erişim tarihi 12 Şubat 2019).

7."Bu görüşme sosyal medyanın diline düştü!", 18.02.2017, http://www.hurriyet.com.tr/galeri-bugorusme-sosyal-medyanin-diline-dustu-40369949 (Erişim tarihi 12 Şubat 2019).

8."Trudeau'ya rakip çıktı! Dünya İspanya Başbakanı'nı konuşuyor", 03.06.2018, http://www.hurriyet.com.tr/galeri-trudeauya-rakip-cikti-dunya-ispanya-basbakanini-konusuyor40856381?p=1 (Erişim tarihi 12 Şubat 2019).

9."Dünyanın en seksi başbakanı: Justin Trudeau", 21.10.2017, http://www.hurriyet.com.tr/kelebek/hayat/dunyanin-en-seksi-basbakani-justin-trudeau-40003968, Erişim tarihi (12 Şubat 2019).

10."Trudeau Ailesi 'Sih' olsayd1...", 22.02.2018, http://www.hurriyet.com.tr/dunya/trudeau-ailesi-siholsaydi-40749733, (Erişim tarihi 28 Ocak 2019).

11."Kanada Başbakanı Justin Trudeau'den Ramazan Bayramı mesajı", 15.06.2018, http://www.hurriyet.com.tr/dunya/kanada-basbakani-justin-trudeauden-ramazan-bayrami-mesaji40868016, Erişim tarihi 12 Şubat 2019).

12."Kareye başbakan girdi!", 21.05.2017, http://www.hurriyet.com.tr/dunya/kareye-basbakan-girdi40464997 (Erişim tarihi 28 Ocak 2019)

13."Kanada Başbakanı'nın şakası sosyal medyayı salladı", 13.07.2018, http://www.hurriyet.com.tr/video/kanada-basbakaninin-sakasi-sosyal-medyayi-salladi-40895473, (Erişim tarihi 12 Şubat 2019).

14."Liderler sohbete dalınca Trudeau dişarıda kaldı", 29.05.2017, http://www.hurriyet.com.tr/dunya/liderler-sohbete-dalinca-trudeau-disarida-kaldi-40473055 (Erişim tarihi 12 Şubat 2019).

15.Ahmet KÜLAHÇI, "Gözler milli marşlarda", 21.03.2018, http://www.hurriyet.com.tr/avrupa/gozlermilli-marslarda-40779213, (Erişim tarihi 5 Ocak 2019).

16."Kanada'daki cami saldırısında yaşamını yitirenler için tören düzenlendi, Başbakan Trudeau da ağladı", $\quad$ 04.02.2017, http://www.hurriyet.com.tr/dunya/kanadadaki-cami-saldirisinda-yasaminiyitirenler-icin-toren-duzenlendi-basbakan-da-agladi-40355325 (Erişim tarihi 28 Ocak 2019).

17."Justin Trudeau'dan Trump'a 'yağmur' göndermesi", 12.11.2018, http://www.hurriyet.com.tr/galerijustin-trudeaudan-trumpa-yagmur-mesaji-41016344?p=7, (Erişim tarihi 12 Şubat 2019). 
18."Ünlü rockçı hayatını kaybetti Kanada Başbakanı gözyaşlarını tutamadı", 19.10.2017, http://www.hurriyet.com.tr/dunya/unlu-rockci-hayatini-kaybetti-kanada-basbakani-gozyaslarinitutamadi-40615353 (Erişim tarihi 12 Şubat 2019).

19."Çin ile Kanada arasında ipler iyice geriliyor!", 15.12.2018, http://www.hurriyet.com.tr/dunya/cin-ile-kanada-arasinda-ipler-iyice-geriliyor-41052814 (Erişim tarihi 12 Mart 2019).

20."Kanada Başbakanı'ndan 'Wanzhou' açıklaması", 07.12.2018,

http://www.hurriyet.com.tr/yerel-haberler/istanbul/merkez/kanada-basbakanindan-wanzhouaciklamasi-41044522 (Erişim tarihi 12 Şubat 2019).

21."Trump'tan Kanada Başbakanı Trudeau'ya: Dersini aldı", 12.06 .2018 , http://www.hurriyet.com.tr/dunya/trumptan-kanada-basbakani-trudeauya-dersini-aldi-40865768, (Erişim tarihi 12 Şubat 2019).

22."Trudeau: Kanada ABD Başkanının kum torbası değil", 03.06.2018, http://www.hurriyet.com.tr/dunya/trudeau-kanada-abd-baskaninin-kum-torbasi-degil-40856660, Erişim tarihi 22 Nisan 2019).

23."Kanada Başbakanı Trudeau'dan Suudi Arabistan açıklaması", 09.08.2018, http://www.hurriyet.com.tr/dunya/kanada-basbakani-trudeaudan-suudi-arabistan-aciklamasi40922870 (Erişim tarihi 23 Mart 2019).

24."Trudeau: Kaşıçı cinayetiyle ilgili daha iyi yantlara ihtiyaç var", 02.12.2018, http://www.hurriyet.com.tr/dunya/trudeau-kasikci-cinayetiyle-ilgili-daha-iyi-yanitlara-ihtiyac-var41037806 (Erişim tarihi: 12 Şubat 2019).

25. "https://www.surveymonkey.com/r/3X66Z59" 